\title{
Folsyre kan øke kreftrisiko
}

\author{
Folsyretilskudd kan gi økt risiko for kreft. Det viser en stor norsk studie \\ publisert i JAMA.
}
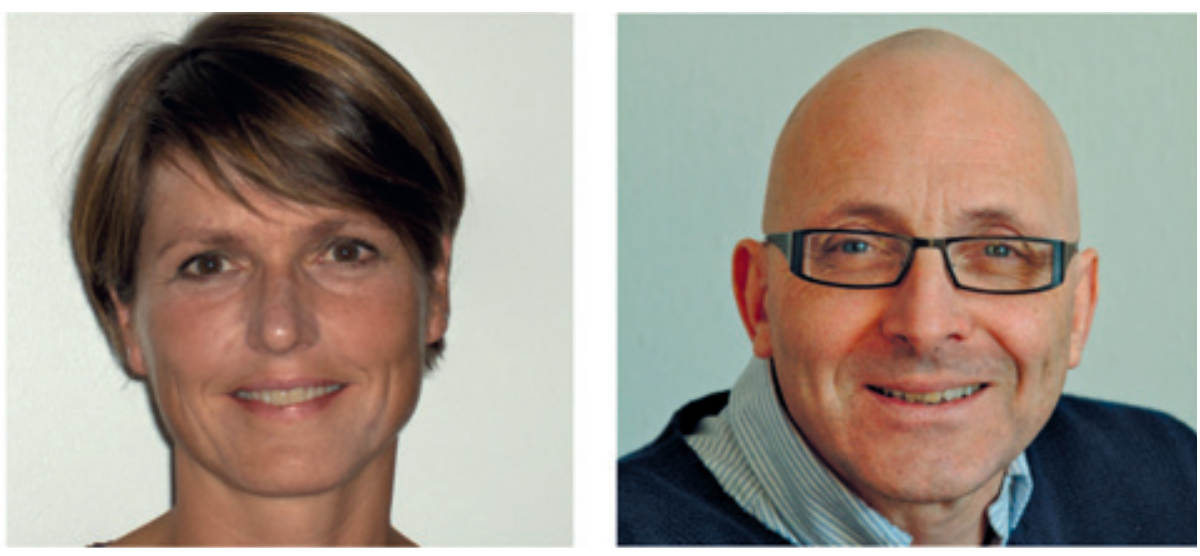

Førsteforfatter Marta Ebbing (foto privat) og andreforfatter Kaare Harald Bønaa (foto Geir Gjelseth)

Totalt 6837 pasienter med iskemisk hjertesykdom deltok i de to norske kliniske forsøkene NORVIT og WENBIT som ble gjennomført i tidsrommet 1998-2005. Behandlingen gikk over 39 måneder. Pasientene ble delt $\mathrm{i}$ fire grupper: folsyre og vitamin $\mathrm{B}_{12}$ med eller uten vitamin $\mathrm{B}_{6}$; vitamin $\mathrm{B}_{6}$ alene eller placebo. Hensikten var å teste om disse intervensjonene hadde gunstig effekt på koronare hendelser, hjerneslag og død.

Behandlingen med folsyre og vitamin $\mathrm{B}_{12}$ senket median homocysteinverdi med $25 \%$, men hadde ingen effekt på de kardiovaskulære endepunktene. Derimot viste nye analyser etter totalt 6,5 års oppfølgingstid at folsyrebehandlingen var forbundet med $21 \%$ økt kreftinsidens, $38 \%$ økt kreftmortalitet og $18 \%$ økt totalmortalitet (1).

- Studien minner oss på at inntak av kunstige vitaminer ikke nødvendigvis er sunt. Mange land, inklusive USA og Canada, har innført obligatorisk folsyretilsetting i visse typer mel og kornvarer. Hensikten er å sikre kvinner i fertil alder adekvate folatnivåer før og under graviditet for å forebygge nevralrørsdefekter hos fosteret, sier førsteforfatter Marta Ebbing ved Hjerteavdelingen, Haukeland universitetssykehus.

- Dosen folsyre man får ved inntak av «normale» mengder fortifiserte mel- og kornprodukter er beregnet til 100-200 $\mu \mathrm{g}$ / dag, men det har vist seg at ganske mange amerikanere får i seg betydelig større mengder ved å spise ekstra fortifiserte frokostblandinger og å ta vitamintilskudd som inneholder folsyre. De kommer da lett opp i daglige doser tilsvarende $800 \mu \mathrm{g}$, slik som pasientene $\mathrm{i}$ vår studie fikk.

I Norge er det ingen folsyrefortifisering av matvarer, og forbruket av folsyre gjennom vitamintilskudd er relativt lavt. Vi mener at folsyre nå bør betraktes som et legemiddel med potensielle bivirkninger, og leger bør være restriktive med å forskrive vitaminpreparater som TrioBe. Vi har også bedt Nasjonalt kunnskapssenter for helsetjenesten om en utredning om folsyre, sier Ebbing.

\section{Bakgrunn og medarbeidere}

Forskerne bak NORVIT- og WENBIT-studiene samarbeidet under planlegging og gjennomføring av de to studiene, og hadde en intensjon om å slå sammen datasettene og foreta kombinerte analyser etter at resultatene fra de to separate studiene hadde blitt publisert. Når det så viste seg at folsyrebehandlingen var forbundet med noe økt kreftrisiko i begge studiene, var det viktig å foreta grundige analyser og forlenge oppfølgingstiden vedrørende kreftendepunkt.

Samarbeidet har så langt ført til denne artikkelen, og en artikkel om effekten av røyking på B-vitaminnivå (2). Flere analyser og artikler er på vei; med detaljerte kliniske data på nærmere 7000 hjertepasienter, blodprøver tatt på tre forskjellige tidspunkter, tusenvis av validerte kliniske endepunkter og gode registerdata, har forskerne rikelig materiale å arbeide med i mange år fremover.

Artikkelen er skrevet av 13 norske forskere: Marta Ebbing, Kaare Harald Bønaa, Ottar Nygård, Egil Arnesen, Per Magne Ueland, Jan Erik Nordrehaug, Knut Rasmussen, Inger Njølstad, Helga Refsum, Dennis W. Nilsen, Aage Tverdal, Klaus Meyer og Stein Emil Vollset.

\section{Erlend Hem}

erlend.hem@medisin.uio.no

Tidsskriftet

\section{Litteratur}

1. Ebbing M, Bønaa KH, Nygård $O$ et al. Cancer incidence and mortality after treatment with folic acid and vitamin B12. JAMA 2009; 302: 2119-26.

2. Ulvik $A$, Ebbing $M$, Hustad $S$ et al. Long and shortlived effects of tobacco smoking on circulating concentrations of B-vitamins. Clin Chem 2010; akseptert for publisering.

\section{Ordforklaringer}

Folsyre er den syntetiske formen for B-vitaminet folat. Folsyre omdannes i organismen til tetrahydrofolater, som virker som koenzymer i biokjemiske transmetyleringsreaksjoner. Den aktive formen av folsyre er 5-metyltetrahydrofolat.

Folat er B-vitamin $\left(B_{9}\right)$ som finnes naturlig i bl.a. grønne grønnsaker og sitrusfrukter.

Hasardratio (HR) er ratioen mellom hasardfunksjonen for to grupper. Hasardfunksjonen uttrykker risikoen (per tidsenhet) for en gitt hendelse (her kreftdiagnose eller død) på et bestemt tidspunkt. Hasardratioen er her den relative risikoen for kreft eller død for dem som fikk folsyre og vitamin $B_{12}$ versus dem som ikke fikk slik behandling. Eksempel: 341 pasienter $(10 \%)$ som hadde fått folsyre og vitamin $\mathrm{B}_{12}$, fikk påvist kreft. Tilsvarende tall for dem som ikke fikk slik behandling var 288 $(8,4 \%)$. Hasardratio ble da 1,21 (95\% KI $1,03-1,41)$.

NORVIT og WENBIT er to studier som springer ut fra hjertemedisinske, epidemiologiske og biokjemiske forskningsmiljøer ved universitetene i Tromsø og Bergen. Utgangspunktet for studiene var homocysteinhypotesen. I 1980- og -90-

årene ble det gjort mange epidemiologiske og noen eksperimentelle studier, også i Norge, som tydet på at homocystein kunne være en årsak til hjerte- og karsykdom. Man ville derfor undersøke om homocysteinsenkende behandling med B-vitaminer kunne bedre prognosen hos pasienter med etablert kardiovaskulær sykdom. De to studiene var initierte av forskerne og var uavhengig av legemiddelindustrien. De er de to største randomiserte, kontrollerte forsøkene som hittil er utført i Norge.

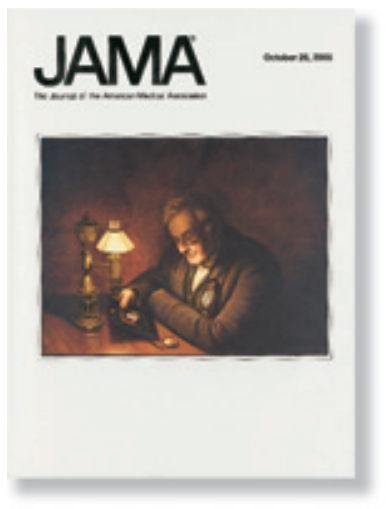

Artikkelen ble publisert 18.11. 2009 i JAMA (www.jama.com), som regnes som en av de «fem store» innen medisinsk publisering ved siden av New England Journal of Medicine, BMJ, Annals of Internal Medicine og The Lancet 